2. The main factors that shape the institutional environment of the ecological and economic system and their impact on the institutional environment and the dynamics of its development to the state of institutional equilibrium are given.

3. Economic conditions that determine the possibilities of transforming the institutional environment of the market of social-ecological forest services to the state of institutional equilibrium are revealed.

4. Strategies for the behavior of the subjects of the ecological and economic system on the formation of economic conditions for achieving the institutional equilibrium of the market for social and ecological forest services are proposed.

\section{References}

1. Nort, D. Instituty, institutsional'nye izmeneniia i funktsionirovanie ekonomiki [Text] / D. Nort. - Moscow: Nachala, 1997. - 412 p.

2. Nort, D. Institutsional'nye izmeneniia, ramki analiza [Text] D. Nort // Voprosy ekonomiki - 1997 - № 3. - P. 6-17.

3. Axelrod, R. An Evolutionary Approach to Norms [Text] / R. Axelrod // American Political Science Review. - 1986. Vol. 80, № 04. - P. 1095-1111. doi:10.1017/s0003055400185016

4. Bromley, D. W. Economic Interests and Institutions: The Conceptual Foundations of Public Policy [Text] / D. W. Bromley. New York. Basil Blackwell, 1989. - 274 p.

5. Williamson, O. E. The New Institutional Economics: Taking Stock, Looking Ahead [Text] / O. E. Williamson // Journal of Economic Literature. - 2000. - Vol. 38, № 3. - P. 595-613. doi:10.1257/jel.38.3.595

6. Heiner, R. The Origin of Predictable Behavior [Text] / R. Heiner // American Economic Review. - 1983. - Vol. 73, № 4. P. $560-595$
7. Arthur, B. Competing Technologies Increasing Returns and Lock - In by Historical Events [Text] / B. Arthur // The Economic Journal. - 1989. - Vol. 99, № 394. - P. 116-131. doi: $10.2307 / 2234208$

8. Tambovtsev, V. Institutsional'noe ravnovesie kak mehanizm institutsional'nyh izmenenii [Text] / V. Tambovtsev // Obshchestvennye nauki i sovremennost'. - 2000. - № 5. - P. 25-38.

9. Valevich, Yu. Rynok institutov i usloviia ego ravnovesiia [Text]/ Yu. Valevich. - Minsk: BGU, 2014. - 312 p.

10. Macouley, S. Non-Contractual Relations in Business: A Preliminary Study [Text] / S. Macouley // American Sociological Review. - 1963. - Vol. 28, № 1. - P. 55-67. doi:10.2307/2090458

\section{ИССЛЕДОВАНИЕ ИНСТИТУЦИОНАЛЬНОГО РАВНОВЕСИЯ РЫНКА СОЦИАЛЬНО-ЗКОЛОГИЧЕСКИХ УСЛУГ ЛЕСА: УСЛОВИЯ И} СТРАТЕГИИ РАЗВИТИЯ

Исследовано состояние институционального равновесия, как таковой, что повышает эффективность функционирования экономической системы. Определено особенности институциональной среды рынка социально-экологических услуг леса, как эколого-экономической системы, экономические условия развития институциональной среды. Приведены стратегии достижения состояния институциональной равновесия

ключевые слова: институциональная среда, институциональное равновесие, институциональные трансакции, рынок социально-экологических услуг, стратегии развития.

Suska Anastasiy, PhD, Corresponding Member of the Academy of Economic Sciences of Ukraine, Head of the Department of Wood Technology and Systems Engineering Forest Complex, Kharkiv Petro Vasylenko National Technical University of Agriculture, Ukraine, e-mai: n.suscka@gmail.com, ORCID: http://orcid.org/0000-0002$7465-1776$

\section{Hodakov V.,} Sokolova $\mathbf{N}$.

\title{
SELECTION OF A SET OF INDICATORS OF ESTIMATION OF SOCIAL AND ECONOMIC SYSTEMS OF REGIONAL TYPE
}

Розглянуто формування наборів показників, що характеризують складні соціально-економічні системи (СЕС) регіонального типу, для вирішення завдання багатофакторного ощінювання. Запропоновано враховувати чинники природно-кліматичного характеру. Розроблено основи методології оцінювання СЕС на основі використання індексів, отриманих в результаті нормування показників, застосування інтегральних згорток, типологізації і ранжирування. Проаналізовано індекси на основі лінійних і квадратичних процедур усереднення. Результати досліджень застосовуються в системах моніторингу та підтримки прийняття рішень.

Ключові слова: рівень інвестичійної привабливості, рівень сталості розвитку, багатофакторне управління, прочедури усереднення, нормування показників.

\section{Introduction}

Among a number of complex systems, socio-economic systems (SES) occupy a special place, which are divided into SES of different levels and types. The most complex, the most global SES is modern civilization.
The more elementary considered SESs consist mainly of three main elements-subsystems: social groups, economic processes and the environment. A social group is primarily an individual and a person. Under the environment is understood the ecological, geographic, natural and climatic environment and metasystem environment. The specific 
quantitative and qualitative characteristics of the listed elements and the relationships between them determine the specific properties of a particular local SES [1, 2].

Local SESs, functioning in the conditions of Western and Eastern Europe, is being investigated.

Management of the development of such classes of SESs requires the solution of a number of tasks, in particular, at the initial stages it is necessary to identify the current state and trends in the development of the system, develop and optimize the scenario of sustainable development at various planning horizons.

The concept of sustainable development requires a comprehensive analysis and consideration of environmental, social, economic, natural and climatic and other factors. And for this it is necessary to solve the problems of determining sets of indicators of sustainable development.

The solution of these problems allows to objectively assess the state of SES, which should be sufficient to identify in full the explicit and indirect properties of SES. Therefore, the tasks of selecting sets of indicators for assessing socio-economic systems are quite relevant.

\section{The object of research of technological audit}

The object of research is classes of socio-economic systems of a regional type, which include countries, regions of Western and Eastern Europe.

Differences in the natural and climatic conditions of Western and Eastern Europe have a universal complex impact on all aspects of the economy and the life of the individual, society and the state, form a different mentality of a person (socium), in both Western and Eastern Europe, different durations of the agricultural working season (shorter and requiring considerably more labor, greater intensity and labor costs in Eastern Europe), a much more unprofitable livestock farming with a significantly higher cost of production in Eastern Europe. Industrial and construction production in Eastern Europe is also characterized by high production costs, more expensive infrastructure, higher production costs, longer payback periods than in Western Europe. The basic needs of the individual in Eastern Europe are higher, and the conditions for their satisfaction are much more modest than in Western Europe.

The climatic conditions of Eastern Europe cause a rise in the cost of life and production and economic activities of man and society.

It should also be taken into account that the society in Eastern Europe does not have sufficient knowledge of natural and climatic factors and differences in climatic conditions in Western and Eastern Europe, as well as in understanding the levels of influence of the FSC on society, economy and culture. The lack of such understanding leads to a decrease in the level of information security of society and the state. Therefore, the task of educating the public is that there are differences in the natural and climatic conditions and they are of a fundamental nature and require extensive coverage of the negative effects of climate on man, society and the economic development of countries and regions and the mass dissemination of scientific and popular science literature, educational and methodological literature on the problems of information security of the society from ignorance and misunderstanding of the impact of natural and climatic conditions on the economy and society. Knowledge and understanding of these differences can play an important role in the development of society, state and globalization of modern society.

\section{The aim and objectives of research}

The aim of research is solution of the problems of selecting a set of indicators for estimating the SES, substantiating the construction of general criteria for the SES estimation indicators of a regional type, expanding the system of indicators to obtain a more objective picture of SES state estimation.

Evaluation is the identification, comparison of the evaluated object with its idealized image (standard, norm). The SES is assessed, i. e. the region and its condition are diagnosed.

\section{Research of existing solutions of the problem}

In Eastern Europe, since 1917, it was time to noticeably weaken the attention of scientists and society to understanding the difference in the natural and climatic conditions of Eastern and Western Europe and the degree of influence of natural and climatic conditions on the history and economy of society and the state. The serious impact of natural and climatic conditions (NCC) on the life and economy of society was rejected, it was believed that the geographical environment can't play a major role in the life of society. The situation began to change after the 90 s of the XX century. Studies of natural and climatic factors in Eastern Europe were carried out by the authors [3-5].

It should be noted the American scientists-researchers, who drew attention to the role of the PCF in the life of the state and society $[6,7]$.

At the present time, the work on the transition to the implementation of the paradigm of «sustainable development of society» is increasingly being carried out, which in turn implies the development of all regions, including individual regions. The term «region» in Russian literature is most often understood as a set of areas of a particular country. Thus, the development of regions as complex socio-economic systems (SES) is an important component of the development of society.

The transition to the paradigm of sustainable development of society on the example of SES requires the selection, analysis and accounting of a large number of indicators and criteria relating to a variety of areas; Economic, ecological, social, geographic, natural-resource, scientific and technical, labor potential [8-10]. A large number of indicators make it difficult to obtain an objective picture of the assessment.

This class of SES is a certain territorially distributed unit that differs from other units of the same level with specific features - geographic, geological, industrial, social, economic, ethnographic, ecological, has a certain integrity, interconnectedness of the elements that form it, solves the problems of multifactorial distributed and hierarchical state anti-crisis management [2]. To this it is necessary to add that the SES data are objects with weakly formalized processes. 
The first and most important tasks on the path of researchers are the tasks of selecting the nomenclature and the number of indicators that allow an objective assessment of the state of SES that should be sufficient to identify in full the explicit, indirect and latent properties of SES relationships [1,2].

\section{Methods of research}

5.1. Feasibility of accounting for climate indicators. At the moment, both domestic and Western researchers do not take into account natural and climatic factors when assessing the state of SES, or when developing management strategies. At the same time, the need to study and monitor the dynamics of natural and climatic processes is relevant [2,9].

The climate is one of the main environmental factors, its change against the background of complex ecological, social and economic situations in Ukraine and throughout Eastern Europe can cause serious socio-economic consequences $[2,9,10]$.

For Eastern Europe, and, consequently, Ukraine is characterized by more severe and negative NCC than for countries of Western Europe, which hamper the population's living and cause higher production, household and infrastructural costs, which leads to higher production costs, a longer payback period, to rise in price of life and economic activity. In addition, the economy of the country is not as developed as the economy of Western European countries and Ukraine is more strongly expressed social tension, stratification in society, a decline in the standard of living of the population. These factors increase the negative impact of natural and climatic factors on the socio-economic and production activities of society. All this indicates the advisability of taking into account natural and climatic factors.

As a generalized criterion for assessment can be used: level of sustainability of the regional development, level of investment attractiveness, level of discomfort, etc. The definition of the type of generalized criterion focuses on the appropriate selection of the evaluating positions and indicators [11, 12].

5.2. Characteristics of the set of indicators. State characteristic of the object of study of the region is determined by a set of indicators (normalized indicators - mental, specific, etc.). The optimal list of indicators should correspond to the following:

- contain not an infinite, but a limited number of indicators;

- reflect all the basic conditions and properties of the socio-economic system;

- be representative - able to reflect them fully and adequately, including in space (taking into account the objective conditions of the regions) and in time (fixing not only the momentary slice using static indicators, but also the dynamics of the situation with the help of indicators);

- be methodically correct - with the values of indicators ordered in one vector (for example, «the more - the better», but taking into account the meaning of the indicators, for example, unemployment, poverty, crime, etc.);

- be structurally mature - without strong disproportions in the number and quality of indicators for selected positions, which can be achieved through aggregation (the formation of composite indicators).
The task of determining a sufficient number of indicators characterizing the SES is complex and important, as this affects the quality of diagnosing (assessing) of SES states and the «quality» of «developed» management decisions [12-14].

The large dimension of the set of indicators (up to hundreds and more), the absence and lack of development of a methodology for obtaining generalized indicators makes it difficult to study the dynamics of such systems, the construction of a DSS and the development of optimal management solutions.

\section{Research results}

The current state of any SES is estimated, as a rule, by a sufficiently large number of particular indicators $\left\{x_{i}\right\}^{n}=1$, each of which reflects one of the sides (entities) of the system. This is a multi-factor evaluation.

Therefore, the natural next step in the study of such systems is reducing their dimensionality, for example, by translational convolution of particular indicators, i. e. transition to an integrated assessment of objects - regions (Fig. 1). In the simplest case, it is the replacement of a certain set of exponents $\left\{x_{i}\right\}_{i=1}^{n}=1$ by a single more generalized exponent $I\left(\left\{x_{i}\right\}_{i=1}^{n}\right)$. This indicator is usually called the index of the system of exponents $\left\{x_{i}\right\}_{i=1}^{n}$. With this approach to lowering the dimension, it is necessary to exclude loss of information about the system under consideration and therefore a certain «reasonable» averaging procedure is based on the construction of any index, for example, the calculation of the arithmetic mean, mean square, geometric mean, and so on.

Transition to a more generalized integrated assessment allows for a comprehensive review of the state of the region, revealing the positive and negative aspects of its development, and conducting a comparative interregional analysis [15]. In this sequence of actions, it is necessary to distinguish the following stages: the formation of a system of indicators, the standardization of indicators, the combination of the values of indicators for the integrated assessment, the typology of regions, the ranking of regions, for example, in terms of development level. Based on this, the choice of the method for calculating the integral index takes place.

Any set of parameters $\left\{x_{i}\right\}_{i=1}^{n}$ can be treated as a vector in an $n$-dimensional Euclidean space. Then every index $I\left(\left\{x_{i}\right\}_{i=1}^{n}\right)$ is a functional on a linear space of dimension $n$ :

$$
I\left(\left\{x_{i}\right\}_{i=1}^{n}\right)=(X), I: R_{n} \rightarrow R_{1} .
$$

The most frequently used (as the most convenient from a computational point of view) are the indicators constructed on the basis of linear averaging procedures: computing the arithmetic mean:

$$
1(X)=\frac{1}{n} \sum_{i=1}^{n} x_{i}
$$

Or more generally - weighted mean:

$$
I_{p}(X)=\frac{1}{n} \sum_{i=1}^{n} p i x i,
$$

where $P=\{p i\}_{i=1}^{n}, 0 \leq p_{i} \leq 1, i=1,2 \ldots n$ - given set of weight coefficients. 
The following commonly used index class is constructed on the basis of quadratic averaging procedures (quadratic functionals): calculating the mean square (Euclidean vector norm):

$$
J(X)=\sqrt{\frac{1}{n}} \sum_{i=1}^{n} x_{i}^{2}=\frac{1}{\sqrt{n}} X,
$$

or more generally - the calculation of the root-mean-square ratio of the vector $X$ from some given optimal vector:

$$
D(X)=\sqrt{\frac{1}{n}} \sum_{i=1}^{n}\left(x_{i}-s_{i}\right)^{2}=\frac{1}{\sqrt{n}} X-S .
$$

In the literature, there is usually no justification for choosing a particular averaging procedure when calculating indices. Known procedures are conducted either at the level of «plausible reasoning» or at the level of «common sense». Therefore, the problem of theoretical substantiation of procedures of generalized selectable indices for a class of complex SES of a regional type is posed. The most commonly used averaging procedures and the indices (1), (2), (4) generated by them have a simple geometric interpretation and are related by a quadratic dependence.

Without loss of generality, let's assume that all admissible states:

$$
X=\left\{x_{i}\right\}
$$

of the investigated SES are located in the cube:

$$
K=\left\{X=\left\{x_{i}\right\}_{i=1}^{n} \in R_{n}: 0 \leq x_{i}<1, I=1,2, \ldots n\right\} .
$$

This can always be achieved by appropriate normalization of the admissible parameters $\{x i\} n i=1$. Let $S-$ a vector in the cube $K$, all components of which are equal to the unit $S=(1,1, \ldots 1)$. Using the approach described in $[8-10,16]$, this vector can be called the optimal vector. Its optimality consists in that it is larger (in the sense of the natural order relation on the space $R n$ ) of any other vector from the cube $K$. Let's note that the simplest linear index (1) coincides, up to a factor of $1 / n$, with the scalar product of the current vector $X$ and optimal vector $S$ :

$$
\begin{aligned}
& (X, S)=\sum_{i=0}^{n} x_{i} s_{i}=\sum_{i=0}^{n}\left(x_{i} 1\right)= \\
& =\sum_{i=0}^{n} x_{i}=n \frac{1}{n} \sum_{i=0}^{n} x_{i}=n^{*} I(X) .
\end{aligned}
$$

Because:

$$
(X, S)=\|X\| \cdot\|S\| \cdot \cos \varphi
$$

where $\varphi$ is the angle between the vectors $X$ and $S$, and the product $\|X\| \cdot \cos \varphi$ is the magnitude of the projection of the vector $X$ on the direction of the vector $S: S:\|X\| \cdot \cos \varphi=$ $=p r_{s} X$, then:

$$
\begin{aligned}
& I(X)=\frac{1}{n}(X, S)=\frac{1}{n}\|X\| \cdot\|S\| \cdot \cos \varphi= \\
& =\frac{1}{n} p r_{s} X \cdot\|S\|=\frac{1}{n} p r_{s} X \cdot \sqrt{n}=\frac{1}{\sqrt{n}} p r_{s} X .
\end{aligned}
$$

Thus, the simplest linear index:

$$
I(X)=\frac{1}{n} \sum_{i=1}^{n} x_{i}
$$

Up to a factor of $1 / \sqrt{n}$ coincides with the projection of the current vector $X$ on the direction of the optimal vector $S$. According to $[9,10]$, the angle $\varphi$ between the vectors $X$ and $S$ is called the normalization angle. Let's note that since $J(X)=\frac{1}{\sqrt{n}}\|X\|$, the indices $I(X)$ and $J(X)$ are related by:

$$
I(X)=\|X\| \cdot\|S\| \cos \varphi=J(X) \cos \varphi .
$$

Representations (5) and (6) for the linear index $I(L)$ make it possible to introduce one more natural index the value of the Euclidean distance from the point $X$ to the straight line generated by the optimal vector $S$ :

$$
\Gamma(L)=\frac{1}{\sqrt{n}} \inf \left\{\|X-\lambda S\|: \lambda \in R_{1}\right\} .
$$

It is clear that the lower bound in (7) (Fig. 1) is attained at some point $M-$ the base of the perpendicular dropped from the point $X$ to the line generated by the vector $S$. The value of $\lambda$ corresponding to this point delivers the minimum of the numerical function:

$$
f_{x}(\lambda)=\frac{1}{\sqrt{n}}\|X-\lambda S\|=\frac{1}{\sqrt{n}} \sqrt{\sum_{i=1}^{n}\left(x_{i}-\frac{1}{\sqrt{n}}\right)^{2}} .
$$

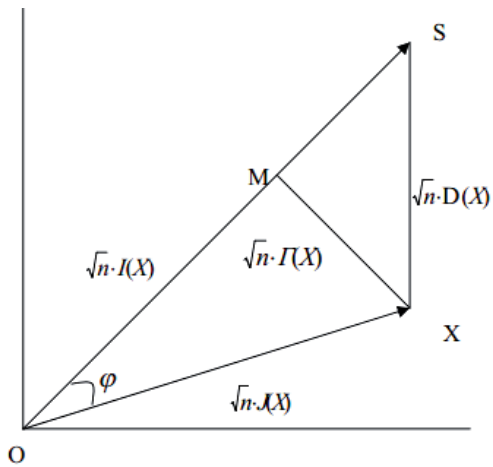

Fig. 1. Geometric representation of the relationship of indices

Equating the derivative of this function to zero:

$$
f_{x}(\lambda)=\frac{1}{\sqrt{n}} \frac{2\left(\sum_{i=1}^{n} x_{i}-\lambda * n\right)}{2 \sqrt{\sum_{i=1}^{n}\left(x_{i}-\lambda\right)^{2}}} .
$$

With it and an explicit representation of the index $\Gamma(X)$ :

$$
\begin{aligned}
& \Gamma(X)=\frac{1}{\sqrt{n}} X-\frac{1}{n} \sum_{i=1}^{n} x_{i} S= \\
& =\sqrt{\frac{1}{n} \sum_{i=1}^{n}\left(x_{i}-\frac{1}{n} \sum_{i=1}^{n} x_{i}\right)^{2}}=\sqrt{\frac{1}{n} \sum_{i=1}^{n}\left(x_{i}-I(X)\right)^{2}} .
\end{aligned}
$$


The index $\Gamma(X)$ has a simple meaning: its value at each point $X$ is the root-mean-square deviation of the components of the vector $X$ from their arithmetic mean.

In the triangle $O S X$ we have the following representations of the lengths of its linear elements in terms of the considered indices:

$$
\begin{gathered}
\|O X\|=\sqrt{n} J(X),\|X S\|=\sqrt{n} D(X), \\
\|O M\|=\sqrt{n} I(X),\|M X\|=\sqrt{n} \Gamma(X) .
\end{gathered}
$$

Further from this triangle it is easy to obtain three connections between the four indexes considered:

$$
\begin{aligned}
& (\sqrt{n} D(X))^{2}=X S^{2}=X-S^{2}=((X-S) \cdot(X-S))= \\
& =X^{2}-2(X \cdot S)+S^{2}=(\sqrt{n} J(X))^{2}-2 n I(X)+(\sqrt{n})^{2},
\end{aligned}
$$

So

$$
\begin{aligned}
& D^{2}(X)=J^{2}(X)-2 \cdot I(X)+1, \\
& O X^{2}=O M^{2}+M X^{2}, \\
& (\sqrt{n} J(X))^{2}=(\sqrt{n} I(X))^{2}+(\sqrt{n} \Gamma(X))^{2} .
\end{aligned}
$$

and

$$
\begin{aligned}
& J^{2}(X)=I^{2}(X)+\Gamma^{2}(X), \\
& S X^{2}=M X^{2}+M S^{2}, \\
& (\sqrt{n} D(X))^{2}=(\sqrt{n} \Gamma(X))^{2}+(O S-O M)^{2}= \\
& =(\sqrt{n} \Gamma(X))^{2}+(\sqrt{n}-\sqrt{n} I(X))^{2} .
\end{aligned}
$$

Then

$$
D^{2}(X)=\Gamma^{2}(x)+(I-I(X))^{2} .
$$

Equations (8)-(10) mean that the quadratic indices do not carry any new information about the state of SES in comparison with the simplest linear index $I(X)$ : they are quadratic functions of $I(X)$ and the coordinates of the vector $X$.

One of the main purposes of any index of the socioeconomic system is the rating evaluation of a given set of states $\left\{X_{j}\right\}_{j=1}^{m}$ of such system. Every functional: $R_{n} \rightarrow R_{1}$ transforms the space $R n$ into a completely ordered set by means of the convention: $X>Y$ if $I(X)>I(Y)$ for any pair of vectors $X, Y \in R_{n}$. The ratio of the total order generated by the simplest linear index (1) has a simple meaning: for any pair of vectors $X, Y \in R_{n}$, the vector whose projection onto the direction of the optimal vector is greater than $I(X)>I(Y)$ is the best, or equivalent, that a vector that is less distant from the direction of the optimal vector $\Gamma(X)<\Gamma(Y)$.

Let's analyze the «reasonableness» of the procedure for constructing linear indices (1), (2). The construction of the index as the mean of the arithmetic meanings of the parameters (1) does not take into account objectively existing differences in the importance of the individual parameters $x_{i}$. For example, an indicator such as GDP per capita should contribute more to the total value of the index than, for example, the area of paved roads per unit area in rural areas. These differences in the degree of importance of the individual parameters $x_{i}$ can be taken into account by assigning to each of the parameters $x_{i}$ the corresponding weighting factor, i. e., constructing a linear index based on the weighted average calculation $I_{p}(X)(2)$. This raises the problem of a «easonable» choice of the weight coefficients $\left\{p_{i}\right\}_{i=1}^{n}$.

Just as the index $I(X)$ is, up to a multiplier, the scalar product of the current vector $X=\left\{X_{j}\right\}_{j=1}^{m}$ and the optimal vector $S=(1,1, \ldots, 1)$, the generalized linear index $I_{p}(X)$ is exactly the scalar product of the current vector $X$ and the weighting factor vector:

$$
P=\left\{p_{i}\right\}_{i=1}^{n}, 0 \leq p_{i} \leq 1, i=1,2, \ldots n .
$$

Thus, the problem of a «reasonable» choice of weight coefficients is the problem of choosing in some sense the optimal vector:

$$
P=\left\{p_{i}\right\}_{i=1}^{n}, 0 \leq p_{i} \leq 1, i=1,2, \ldots n .
$$

If the optimality of a vector is understood in the sense of the natural order on the space $R_{n}$, then in the cube $K$ there is a unique vector that is optimal in this sense this is the vector $S$. Therefore, in practical applications, the choice of the «optimal» vector $P$ is carried out with the help of a system of expert estimates [17] that add an element of subjectivism both in the meaning of the index $I_{p}(X)$ itself, and of the conclusions on its basis on the current state of the SES.

In this case, assigning the components of the optimal weight factor vector:

$$
P=\left\{p_{i}\right\}_{i=1}^{n}, 0 \leq p_{i} \leq 1, i=1,2, \ldots n,
$$

the expert is guided not only by his experience and knowledge of the general structure of the admissible SES states, but takes into account the structure of the set of states $\left\{X_{j}\right\}_{j=1}^{m}$, proposed to him for analysis, having in mind, in the final analysis, the rating evaluation of this set using the constructed index. That is, for the expert, the concept of optimality of the weighting coefficient vector is not global in nature, but is tied to a given set of states $\left\{X_{j}\right\}_{j=1}^{m}$

But every set of vectors $\left\{X_{j}\right\}_{j=1}^{m} \in R_{n}$ has an equilibrium point, the center of gravity of this system of vectors. The vector $R_{n}$, corresponding to this point should be considered as the natural optimal vector for a given set of states $\left\{X_{j}\right\}_{j=1}^{m}$ of SES, since the importance of equilibrium states of economic states is well known [13, 14]. If a system of points $\left\{X_{j}\right\}_{j=1}^{m} \in R_{n}$ is given and at each point $X_{j}$ the mass $M_{j}$ is concentrated, then the center of gravity of such a system is defined by the equality:

$$
X_{0}=\frac{\sum_{j=1}^{m} M_{j} X_{i}}{\sum_{j=1}^{m} M_{j}} .
$$

Let's note that for a vector $\mathrm{S}=(1,1, \ldots 1)=\sum_{i=1}^{n} e_{i}$ optimal in the sense of the natural order on the space $R_{n}$, the vector $S_{0}=\frac{1}{n} S$ is the center of gravity of the system of unit vectors $\left\{e_{i}\right\}_{i=1}^{n}$ of the natural basis of a Euclidean space, if assume that in each unit vector there is a unit mass. In addition, the vector $S_{0}$ is the Nash equilib- 
rium point for the closed convex hull of the unit vectors $C=\operatorname{conv}\left(\left\{e_{i}\right\}_{i=1}^{n}\right)$ : for any vector $\left\{x_{i}\right\}_{i=1}^{n} \in C$ at least one of its coordinates does not exceed the corresponding coordinate of the vector $S S_{0}\left(x_{i} \leq 1 / n\right)$.

Let's assume that at each point of the given set of states $\left\{X_{i}\right\}_{i=1}^{n} \in K$ the unit mass is concentrated and let:

$$
X_{0}=\frac{1}{m} \sum_{j=1}^{m} X_{j}
$$

the center of gravity of the corresponding system. Then each component of the vector $x_{0}$ is the arithmetic mean of the values of the corresponding component of the vectors $\left\{X_{j}\right\}_{j=1}^{m}$ :

$$
x_{0, i}=\frac{1}{m} \sum_{j=1}^{m} x_{i, i}, i=1,2 \ldots n, X_{j}=\left\{x_{i, j}\right\}_{i=1}^{n}, j=1,2 \ldots m .
$$

Let's denote:

$$
M_{i}=\frac{1}{m} \sum_{j=1}^{m} x_{i, i}, i=1,2 \ldots n, M=\sum_{i=1}^{n} M_{i} .
$$

Further, let $p_{i}=M_{i} / M, \quad i=1,2 . . n$ and $P=\left\{p_{i}\right\}_{i=1}^{n}$. It is clear that $0 \leq p_{i} \leq 11$ for any $I=1,2 \ldots n$ and $\sum_{i=1}^{n} p_{i}=1$. Then, by construction, the weight vector $P$ only differs from the center of gravity of the system of vectors $\left\{X_{j}\right\}_{j=1}^{m}$ : by the factor $1 / M$ :

$$
P=\frac{1}{M} \cdot X_{0} .
$$

$P$ is the point of intersection of the line $\lambda X_{0}$ with the closed convex hull of the unit vectors $C=\operatorname{conv}\left(\left\{e_{i}\right\}_{i=1}^{n}\right)$. Let's note that the vector of weight coefficients $\mathrm{P}$ itself can be treated as the center of gravity of the system of unit vectors that in each unit vector $e_{i}$ the mass $M_{i}$ (11) is concentrated.

Since Euclidean space is self-adjoint, every continuous linear functional $\mathrm{f}$ on it can be treated as a vector of the space $X_{f}=\left\{f_{i}\right\}_{i=1}^{n} \in R_{n}$, and the action of this functional on an arbitrary element $X=\left\{x_{i}\right\}_{i=1}^{n} \in R_{n}$ reduces to computing the scalar product of the vectors $X_{f}$ and $X: f(X)=\left(X_{f} \cdot X\right)=\sum_{i=1}^{n} f_{i} X_{i}$. With respect to the SES indices, this means that each linear index $I(X)$ is generated by some «optimal» vector $S=\left\{X_{i}\right\}_{i=1}^{n}$ and its value at every point $X \in R_{n}$ coincides the scalar product of the vectors $S$ and $X I(X)=\sum_{i=1}^{n} s_{i} x_{i}=(S \cdot X)$ up to a factor. It can always be assumed (by normalizing the vector $S$ by the quantity $\sum_{i=1}^{n} S_{i}$ such that $\sum_{i=1}^{n} S_{i}=1$, that is, the optimal vector $S$ lies in the closed convex hull of the unit vectors $S \in C=\operatorname{conv}\left(\left\{e_{i}\right\}_{i=1}^{n}\right)$. Therefore, every linear index can be computed using the weighted average procedure $I_{p}(X)(2)$ for some set of weight coefficients $P=\left\{p_{i}\right\}_{i=1}^{n}, 0 \leq 1, p_{i} \leq 1$, $i=1,2 \ldots n$. Moreover, among all such indices, the best index is the index constructed on the basis of the center of gravity of the given system of states $X_{i j-1}^{m} \in K$ (12), since it is unique to the equilibrium state of this system.

\section{SWOT analysis of research results}

Strengths. Thus, the task of justifying the choice of the nomenclature, the number of indicators and the construction of procedures for generalizing the selectable indices for the SES class of the regional type is solved. The obtained results are used in the construction of the DSS by regions of Ukraine, which allows more fully to solve the problems of multifactor estimation and management of complex SES of a regional type. The developed system uses about 70 indicators to assess the sustainability of the region (area) development, more than 80 - to assess the investment attractiveness of the regions [2, 10]. The used indicators relate to the following diverse areas: economic-geographic, resource-resource, labor, economic, infrastructure potential, scientific and technical, health, investment, natural and climatic. For the first time, the natural and climatic potential is introduced into the indicators, which is characterized by 7 partial indica-

\begin{tabular}{|c|c|c|}
\hline \multirow{7}{*}{$\begin{array}{l}\text { Natural } \\
\text { and climatic } \\
\text { potential (NCP) }\end{array}$} & 1 & Average annual isotherms (summer), ${ }^{\circ} \mathrm{C}$ \\
\hline & 2 & Average annual isotherms (winter), ${ }^{\circ} \mathrm{C}$ \\
\hline & 3 & Average annual level of precipitation, $\mathrm{mm} \mathrm{Hg}$ \\
\hline & 4 & Air humidity, \% \\
\hline & 5 & Average annual wind force, $\mathrm{m} / \mathrm{s}$ \\
\hline & 6 & Depth of soil freezing, m \\
\hline & 7 & Number of sunny days \\
\hline
\end{tabular}
tors (Table 1)

Table 1

List of indicators of natural and climatic potential

The information technology of SES estimation as objects of DSS is shown in Fig. 2.

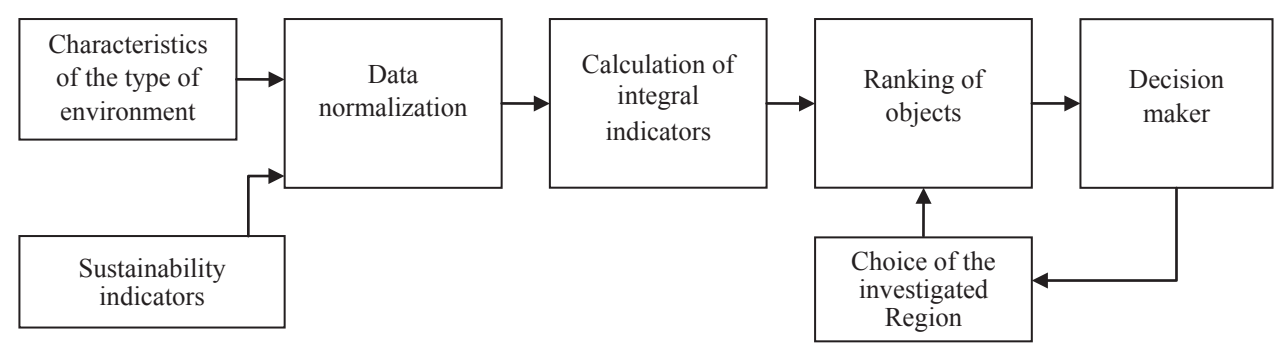

Fig. 2. Information technology for assessing the sustainability of development (investment attractiveness) of regions - SES of the regional type 
Weaknesses. The large dimension of the set of indicators requires a decrease in the dimension of the partial indicators, which is realized by progressive convolution of the indicators. This construction of the indices does not take into account the differences in the importance of individual indicators, which, in the analysis, can now be taken into account by assigning the appropriate weight coefficients using the system of expert assessments, using the experience and knowledge of experts for whom the notion of optimality of weight coefficients is not global in nature, but is tied to a particular system (SES) [17-19].

Opportunities. This system can be used in the strategy of the development of the regions of Ukraine.

Threats. Insufficient awareness (enlightenment) of the society regarding the importance of natural and climatic factors leads to their underestimation when forming strategic plans for the development of regions.

\section{Conclusions}

Thus, a solution to the complex task of selecting a set of indicators for assessing socio-economic systems of a regional type is formed and tested. A methodology is developed for selecting a set of SES estimation indicators.

Theoretical justification of the assessment methodology in the form of a set of procedures for selecting indicators, combining them into a single integrated indicator by adding natural and climatic indicators allows to obtain more complete and reliable estimates of SES management, because it allows to take into account more factors. This multi-factor assessment is used both in the construction of DSS by regional systems and in the construction of monitoring systems for individual territories, regions, etc.

\section{References}

1. Gubarenko, E. V. Modeli i metody upravleniia ustoichivym razvitiem sotsial'no-ekonomicheskih sistem [Text] / E. V. Gubarenko, A. O. Ovezgeldyev, E. G. Petrov; ed. by E. G. Petrov. Kherson: Grin' D. S., 2013. - 252 p.

2. Hodakov, V. E. Prirodno-klimaticheskie faktory i razvitie sotsial'no-ekonomicheskih sistem [Text] / V. E. Hodakov, N. A. Sokolova. - Searbruken (Deutschland): Lambert Academic Publishing, 2016. $-604 \mathrm{p}$.

3. Moiseev, N. N. S mysliami o budushchem Rossii [Electronic resource] / N. N. Moiseev. - 2000. - Available at: \www/URL http://www.yabloko.ru/Union/MMYA/future/moiseev.html

4. Milov, L. V. Prirodno-klimaticheskii faktor i tip rossiiskogo istoricheskogo protsessa [Text] / L. V. Milov. - Moscow: ROSSEP, 1998. - 574 p.

5. Parshev, A. P. Pochemu Rossiia ne Amerika [Text] / A. P. Parshev. - Moscow: Krymskii most-9D, Forum, 1999. - 245 p.

6. Kaplan, R. Mest' geografii. Chto mogut rasskazat' geograficheskie karty o griadushchih konfliktah i bitve protiv neizbezhnogo [Text] / R. Kaplan. - Moscow: Kolibri, Azbuka - Attinus, 2015. - 316 p.

7. Paips, R. Rossiia pri starom rezhime [Text] / R. Paips. - Moscow: Nezavisimaia gazeta, 1993. - $159 \mathrm{p}$.

8. Indicators of Sustainable Development: Guidelines and Methodologies [Text]. - NY: Department of Economics and Social Affairs, 2013. - 99 p. doi:10.18356/6ab82bca-en

9. Zgurovsky, M. Z. Stalyi rozvytok u hlobalnomu i rehionalnomu vymirakh [Text] / M. Z. Zgurovsky. - Kyiv: NTU »KPI», 2006. -83 p.
10. Zgurovsky, M. Z. Rol' inzhenernoi nauki i praktiki v ustoichivom razvitii obshchestva [Text] / M. Z. Zgurovsky, H. A. Statiukha // Systemni doslidzhennia ta informatsiini tekhnolohii. 2007. - № 1. - P. 19-38.

11. Environmental Sustainability Index [Text]: Main Report. Yale Center for Environmental Law and Policy, 2005. - 63 p.

12. Hodakov, V. E. Modeli otsenivaniia sostoianiia territorial'noproizvodstvennyh sotsial'no-ekonomicheskih sistem [Text] / V. E. Hodakov, N. A. Sokolova, D. V. Khapov // Problemy informatsiinykh tekhnolohii. - 2012. - № 1 (11). - P. 6-11.

13. Zaitseva, L. M. Metodolohiia kompleksnoi otsinky rivnia sotsialno-ekonomichnoho rozvytku oblasti ta yii administratyvnoterytorialnykh odynyts [Text] / L. M. Zaitseva, S. M. Serohin, V. O. Fediushychev. - Dnipropetrovsk: DRIDU NADU, 2003. - $132 \mathrm{p}$

14. Bandur, S. H. Suchasna rehionalna sotsialno-ekonomichna polityka derzhavy: teoriia, metodolohiia, praktyka [Text] / S. I. Bandur, T. A. Zaiets, L. S. Teron. - Kyiv: RVPS Ukr. NANUkr., 2002. -250 p.

15. Mironova, T. L. Sotsial'no-ekonomicheskoe razvitie regiona: diagnostika i territorial'noe planirovanie [Text] / T. L. Mironova. Simferopol: KRP »Krymuchpedgiz», 2008. - 240 p.

16. Poburko, Ya. O. Monitorynhovi otsiniuvannia skladnykh sotsialno-ekonomichnykh yavyshch rozvytku rehionu [Text] / Ya. O. Poburko. - Lviv: Instytut rehionalnykh doslidzhen, 2006. - $306 \mathrm{p}$

17. Volynskii, G. V. O faktorah, opredeliaiushchih investitsionnyi klimat (investitsionnuiu privlekatel'nost') [Text] / G. V. Volynskii, Yu. I. Gorbacheva // Biznes-Inform. - 2007. - № 7. P. $45-46$

18. Zgurovsky, M. The Sustainable Development Global Simulations in Respect of Quality and Safety of Human Life [Text] / M. Zgurovsky. - Kyiv: Polytekhnika, 2007. - 218 p.

19. Kriuchkovskii, V. V. Introspektivnyi analiz. Metody i sredstva ekspertnogo otsenivaniia [Text]: Monograh / V. V. Kriuchkovskii, E. G. Petrov, N. A. Sokolova, V. E. Hodakov. - Kherson: Grin’ D. S., 2011. - 168 p.

\section{ВЫБОР НАБОРА ПОКАЗАТЕЛЕЙ ОЦЕНИВАНИЯ СОЦИАЛЬНО- ЭКОНОМИЧЕСКИХ СИСТЕМ РЕГИОНАЛЬНОГО ТИПА}

Рассмотрено формирование наборов показателей, характеризующих сложные социально-экономические системы (СЭС) регионального типа, для решения задачи многофакторного оценивания. Предложено учитывать факторы природно-климатического характера. Разработаны основы методологии оценивания СЭС на основе использования индексов, полученных в результате нормирования показателей, применения интегральных сверток, типологизации и ранжирования. Проанализированы индексы на основе линейных и квадратичных процедур усреднения. Результаты исследований применяются в системах мониторинга и поддержки принятия решений.

Ключевые слова: уровень устойчивости развития СЭС, уровень инвестиционной привлекательности, процедуры усреднения, нормирование показателей.

Hodakov Viktor, Doctor of Technical Sciences, Professor, Head of the Department of Informational Technologies, Kherson National Technical University,Ukraine, e-mail: hodakov.victor@gmail.com, ORCID: http://orcid.org/0000-0002-8188-9125

Sokolova Nadezhda, Doctor of Technical Sciences, Professor, Head of the Department of Economic Cybernetics and Project Management, Kherson National Technical University, Ukraine, e-mail: sokolova.nadezhda.@gmail.com, ORCID: http://orcid.org/0000-00029949-4973 